\title{
DUKUNGAN SOSIAL DAN HUBUNGANNYA DENGAN TINGKAT DEPRESI PADA NARAPIDANA ANAK
}

\author{
Fitri Maharani Sukma1, Ria Utami Panjaitan² \\ ${ }^{1}$ Fakultas Ilmu Keperawatan Universitas Indonesia \\ ${ }^{2}$ Departemen Keperawatan Jiwa Fakultas Ilmu Keperawatan Universitas Indonesia \\ riautamip71@gmail.com
}

\begin{abstract}
ABSTRAK
Dampak penahanan terhadap narapidana anak ialah rendahnya dukungan sosial. Dukungan sosial yang rendah menjadi salah satu faktor penyebab depresi pada narapidana anak. Penelitian ini bertujuan untuk mengetahui hubungan dukungan sosial dengan tingkat depresi pada narapidana anak di Lembaga Pembinaan Khusus Anak tahun 2018. Metode penelitian menggunakan desain penelitian deskriptif analitik dengan pendekatan cross sectional pada 93 narapidana anak. Instrumen pada penelitian ini ialah kuesioner Interpersonal Support Evaluation List (ISEL) untuk dukungan sosial dan Beck Depression Inventory-II (BDI-II) untuk tingkat depresi. Analisa data yang digunakan yaitu analisa univariat dan bivariat dengan uji chi-square. Jenis uji chi-square yang digunakan ialah independency test untuk menentukan ada tidaknya hubungan antara dukungan sosial dengan tingkat depresi. Hasil penelitian menunjukkan ada hubungan dukungan sosial dengan tingkat depresi pada narapidana anak di Lembaga Pembinaan Khusus Anak tahun 2018 dengan nilai $p$ value yaitu 0,022 ( $p$ value $\leq$ 0,05). Meningkatkan dukungan sosial, skrining kesehatan mental, terapi kognitif, dan terapi psikoedukasi perlu dilakukan sebagai upaya untuk mempertahankan status kesehatan mental dan mencegah serta menangani depresi pada narapidana anak.
\end{abstract}

Kata kunci: Dukungan sosial, depresi, narapidana anak

\section{SOCIAL SUPPORT AND RELATIONSHIP WITH THE LEVEL OF DEPRESSION IN CHILDREN'S INVITATION}

\begin{abstract}
The consequence of detention on child inmates is low social support. Low social support becomes one of the factors contributing depression among child inmates. This research aims to find out the correlation between the social support and level of depression among child inmates at Lembaga Pembinaan Khusus Anak. The methodology of this research is analytical descriptive design with the cross-sectional approach to 93 child inmates. The research instruments are Interpersonal Support Evaluation List (ISEL) and Beck Depression Inventory-II (BDI-II) questionaire. This research uses univariate and bivariate analyses with chi-square test. The test type of chi-square test is used in this research is independency test to determine the relationship between social support and level of depression. The result of this research shows the positive correlation between social support and level of depression among child inmates at Lembaga Pembinaan Khusus Anak in which the p value is 0.022 ( $p$ value $\leq 0.05$ ). Improving social support, mental health screening, cognitive therapy and psychoeducation therapy should be done in effort to maintain mental health status, prevent and handle depression among child inmates.
\end{abstract}

Key words : social support, depression, child inmates.

\section{PENDAHULUAN}

Jumlah tahanan yang terus meningkat membuat kesehatan mental narapidana menjadi perhatian khusus dengan tingkat bunuh diri enam kali lebih tinggi daripada populasi umum (Geitona \& Milioni, 2016).Salah satu masalah kesehatan mental yang masih umum terjadi pada kalangan narapidana ialah depresi. Survei yang dilakukan terhadap 23.000 narapidana menunjukkan prevalensi depresi mayor 10-12\% (Fazel \& Baillargeon, 2011).Pemaparan oleh Perawat di Lembaga Pembinaan Khusus Anak (LPKA), narapidana anak dengan stresor yang tinggi dialami saat awal masuk dan akan keluar LPKA. Menurut Lambie \& Randell (2013) dalam Sulastri (2013), pada awal penanahan narapidana anak akan menunjukkan tanda dan gejala stres yang mengarah pada depresi. Hal ini dapat disebabkan karena pada narapidana anak 
terjadi transisi kehidupan. Perpisahan dengan orang tua merupakan dampak yang paling berpengaruh terhadap munculnya tanda dan gejala depresi pada narapidana anak di LPKA yang berada pada rentang usia 14-18 tahun. Narapidana anak menunjukkan tanda dan gejala depresi seperti ketakutan tidak diterima di masyarakat, khawatir tidak memiliki masa depan, mengatakan sering merasa sedih karena tidak dapat dengan bebas bertemu orang tua, dan muncul pemikiran negatif seperti diri sendiri ialah penyebab kesusahan keluarga.

Menurut Beyen, Dadi, Dachew, Muluneh \& Bisetegn (2017), terdapat faktor di penjara berkontribusi terhadap kesehatan mental, terutama pada depresi yaitu dukungan sosial.Dukungan sosial menjadi koping yang dapat menurunkan dampak negatif stres dan depresi. Dukungan sosial yang didapatkan oleh individu dapat meningkatkan kesejahteraan psikologis dan mempertahankan individu dari kondisi depresi dengan memberikan bantuan, penguatan, perhatian, dan solusi terhadap masalah yang dihadapi individu (Cohen, 2004 dalam Neufeld \& Harrison, 2010).Bentuk dukungan sosial telah dikategorikan dalam beragam cara, seperti instrumental, emosional, dan informasional (Cohen, 2004 dalam Neufeld \& Harrison, 2010).Narapidana anak memiliki kebutuhan akan dukungan sosial baik berupa emosional seperti sebuah ekspresi empati dan perhatian yang hanya pada orang tersebut (De Claire \& Dixon, 2016). Banyak penelitian yang dilakukan pada populasi yang berbeda menunjukkan bahwa depresi tinggi terjadi diantara individu dengan dukungan sosial yang rendah. Alasan yang mungkin dijelaskan ialah dengan kurangnya dukungan sosial dapat menyebabkan peningkatan tekanan psikologis (psikologis distres).

Penelitian bertujuan untuk mengetahui hubungan dukungan sosial dengan tingkat depresi pada narapidana anak. Penelitian ini diharapkan menjadi perhatian bagi perawat, petugas kesehatan lainnya, dan pihak LPKA bahwa pencegahan dan penanganan depresi pada narapidana penting untuk dilakukan.

\section{METODE}

Penelitian ini menggunakan desain penelitian deskriptif analitik dengan pendekatan cross sectional pada 93 narapidana anak (total sampling) di Lembaga Pembinaan Khusus Anak Tangerang dan menggunakan analisa data univariat dan bivariat. Analisa bivariat menggunakan uji chi-square jenis independency test digunakan untuk menentukan ada tidaknya hubungan antara dukungan sosial dengan tingkat depresi. Etika penelitian yang diterapkan yaitu respect for person,beneficence, dan justice. Penelitian ini telah melalui proses kaji etik dan dinyatakan lolos kaji etik oleh Komite Etik PenelitianFakultas Ilmu Keperawatan Universitas Indonesia.

Pengumpulan data menggunakan instrumen yaitu kuesionerInterpersonal Support Evaluation List (ISEL) mengidentifikasi dukungan sosial dan untuk mengukur tingkat depresi yaitu Beck Depression Inventory-II (BDI-II). Dukungan sosial yang dianalisa terdiri atas tiga bentuk, yaitu appraisal support, belonging support, dan tangible support. Klasifikasi tingkat depresi menurut Farinde (2013), terbagi atas depresi minimal (0-9), ringan (10-16), sedang (17-29), dan berat (3063).Data akan diolah dengan langkah editing, coding, processing, cleaning, dan tabulating. Kemudian, data dianalisis dengan analisa univariat dengan uji mean, median, SD, frekuensi, dan presentase dan analisa bivariat menggunakan uji chi-squarejenis independency test.

\section{HASIL}

Hasil penelitian ini mengenai karakteristik responden didapatkan rata-rata usia responden 16,90 tahun. Reesponden yang menempuh pendidikan SMA/SMK sebanyak 51 responden (54,8\%), SMP sejumlah 21 responden $(22,6 \%)$, dan SD sejumlah 21 responden $(22,6 \%)$. Responden paling banyak menerima vonis hukuman $1-9$ tahun yaitu 81 responden $(87,1 \%), \quad<1$ tahun sebanyak 8 responden $(8,6 \%)$, dan $\geq 10$ tahun 4 responden $(4,3 \%)$. Responden telah tinggal di LPKA dengan ratarata waktu 10,12 bulan. Sejumlah 13 responden $(14,0 \%)$ ditahan akibat kasus perampokan/pencurian, 27 responden $(29,0 \%)$ narkoba, 13 responden (14,0\%) penganiayaan, 18 responden $(19,3 \%)$ pembunuhan, dan 22 responden $(23,7 \%)$ kasus lainnya (perkosaan, pencabulan, judi, kekerasan, dan penculikan). Sejumlah 86 responden $(92,5 \%)$ menerima kunjungan dan 7 responden $(7,5 \%)$ tidak menerima kunjungan. Sebanyak 7 responden $(7,5 \%)$ tidak menerima kunjungan baik dari keluarga maupun bukan keluarga, 74 responden $(79,6 \%)$ menerima kunjungan dari keluarga, dan 12 responden $(12,9 \%)$ responden menerima kunjungan dari bukan keluarga. 
Dukungan sosial pada penelitian ini terbagi atas rendah dan tinggi, berdasarkan nilai cut off point mean pada masing-masing yaitu dukungan sosial 59, belonging support 20, appraisal support 19, dan tangible support 19. Presentase responden dengan dukungan sosial rendah sebesar $52,7 \%$ dan dukungan sosial tinggi 47,3\%. Responden dengan appraisal support rendah sebesar 50,5\% dan appraisal support tinggi $49,5 \%$. Responden dengan belonging support rendah 45,2\% dan tinggi 54,8\%.
Responden dengan tangible support rendah sebesar 53,8\% dan tinggi sebesar 46,2\%. Hasil analisa tingkat depresi pada narapidana anak didapatkan, responden paling banyak mengalami tingakat depresi sedang $(35,5 \%)$, depresi minimal $(28,0 \%)$, depresi ringan $(28,0 \%)$, dan depresi berat $(8,6 \%)$. Analisa hubungan antara dukungan sosial (appraisal support, belonging support, dan tangible support) ditunjukkan pada tabel 1 sampai 4 .

Tabel 1.

Analisis Hubungan Dukungan Sosial dengan Tingkat Depresi pada Narapidana Anak (n=93)

\begin{tabular}{|c|c|c|c|c|c|c|c|c|c|c|c|}
\hline \multirow{3}{*}{ Dukungan Sosial } & \multicolumn{8}{|c|}{ Tingkat Depresi } & \multirow{2}{*}{\multicolumn{2}{|c|}{ Total }} & \multirow{2}{*}{$\begin{array}{c}p \\
\text { value }\end{array}$} \\
\hline & \multicolumn{2}{|c|}{ Minimal } & \multicolumn{2}{|c|}{ Ringan } & \multicolumn{2}{|c|}{ Sedang } & \multicolumn{2}{|c|}{ Berat } & & & \\
\hline & $\mathrm{n}$ & $\%$ & $\mathrm{n}$ & $\%$ & $\mathrm{n}$ & $\%$ & $\mathrm{n}$ & $\%$ & $\mathrm{n}$ & $\%$ & \\
\hline Rendah & 10 & 20,4 & 10 & 20,4 & 23 & 46,9 & 6 & 12,2 & 49 & 100 & \\
\hline Tinggi & 16 & 36,4 & 16 & 36,4 & 10 & 22,7 & 2 & 4,5 & 44 & 100 & 0,022 \\
\hline Jumlah & 26 & 28,0 & 26 & 28,0 & 33 & 35,5 & 8 & 8,6 & 93 & 100 & \\
\hline
\end{tabular}

Tabel 2.

Analisis Hubungan Appraisal Support dengan Tingkat Depresi pada Narapidana Anak (n=93)

\begin{tabular}{|c|c|c|c|c|c|c|c|c|c|c|c|}
\hline \multirow{3}{*}{$\begin{array}{c}\text { Appraisal } \\
\text { Support }\end{array}$} & \multicolumn{8}{|c|}{ Tingkat Depresi } & \multirow{2}{*}{\multicolumn{2}{|c|}{ Total }} & \multirow{3}{*}{$\begin{array}{c}p \\
\text { value }\end{array}$} \\
\hline & \multicolumn{2}{|c|}{ Minimal } & \multicolumn{2}{|c|}{ Ringan } & \multicolumn{2}{|c|}{ Sedang } & \multicolumn{2}{|c|}{ Berat } & & & \\
\hline & $\mathrm{f}$ & $\%$ & $\mathrm{f}$ & $\%$ & $\mathrm{f}$ & $\%$ & $\mathrm{f}$ & $\%$ & $\mathrm{f}$ & $\%$ & \\
\hline Rendah & 10 & 21,3 & 9 & 19,1 & 23 & 48,9 & 5 & 10,6 & 47 & 100 & \\
\hline Tinggi & 16 & 34,8 & 17 & 37,0 & 10 & 21,7 & 3 & 6,5 & 46 & 100 & 0,024 \\
\hline
\end{tabular}

Berdasarkan tabel 2 diketahui ada hubungan appraisal support dengan tingkat depresi pada narapidana anak di Lembaga Pembinaan Khusus Anak Tangerang dengan nilai $p$ value yaitu 0,024 ( $p$ value $\leq 0,05)$.
Tabel 3 menunjukkan bahwa ada hubungan belonging support dengan tingkat depresi pada narapidana anak di Lembaga Pembinaan Khusus Anak Tangerang dengan nilai $p$ value yaitu $0,001 \quad(p$ value $\leq 0,05)$.

Tabel 3.

Analisis Hubungan Beloning Support dengan Tingkat Depresi pada Narapidana Anak (n=93)

\begin{tabular}{|c|c|c|c|c|c|c|c|c|c|c|c|}
\hline \multirow{3}{*}{$\begin{array}{c}\text { Belonging } \\
\text { Support }\end{array}$} & \multicolumn{8}{|c|}{ Tingkat Depresi } & \multirow{2}{*}{\multicolumn{2}{|c|}{ Total }} & \multirow{3}{*}{$\begin{array}{c}p \\
\text { value }\end{array}$} \\
\hline & \multicolumn{2}{|c|}{ Minimal } & \multicolumn{2}{|c|}{ Ringan } & \multicolumn{2}{|c|}{ Sedang } & \multicolumn{2}{|c|}{ Berat } & & & \\
\hline & $\mathrm{f}$ & $\%$ & $\mathrm{f}$ & $\%$ & $\mathrm{f}$ & $\%$ & $\mathrm{f}$ & $\%$ & $\mathrm{f}$ & $\%$ & \\
\hline Rendah & 5 & 11,9 & 10 & 23,8 & 20 & 47,6 & 7 & 16,7 & 42 & 100 & \\
\hline Tinggi & 21 & 41,2 & 16 & 31,4 & 13 & 25,5 & 1 & 2,0 & 51 & 100 & 0,001 \\
\hline
\end{tabular}

Tabel 4.

Analisis HubunganTangible Support dengan Tingkat Depresi pada Narapidana Anak ( $\mathrm{n}=93$ )

\begin{tabular}{|c|c|c|c|c|c|c|c|c|c|c|c|}
\hline \multirow{3}{*}{$\begin{array}{l}\text { Tangible } \\
\text { Support }\end{array}$} & \multicolumn{8}{|c|}{ Tingkat Depresi } & \multirow{2}{*}{\multicolumn{2}{|c|}{ Total }} & \multirow{3}{*}{$\begin{array}{c}p \\
\text { value }\end{array}$} \\
\hline & \multicolumn{2}{|c|}{ Minimal } & \multicolumn{2}{|c|}{ Ringan } & \multicolumn{2}{|c|}{ Sedang } & \multicolumn{2}{|c|}{ Berat } & & & \\
\hline & $\mathrm{f}$ & $\%$ & $\mathrm{f}$ & $\%$ & $\mathrm{f}$ & $\%$ & $\mathrm{f}$ & $\%$ & $\mathrm{f}$ & $\%$ & \\
\hline Rendah & 12 & 24,0 & 11 & 22,0 & 22 & 44,0 & 5 & 10,0 & 50 & 100 & \\
\hline Tinggi & 14 & 32,6 & 15 & 34,9 & 11 & 25,6 & 3 & 7,0 & 43 & 100 & 0,218 \\
\hline
\end{tabular}


Hasil analisa data dari tabel 4 diketahui bahwa tidak ada hubungan antara tangible support dengan tingkat depresi pada narapidana anak di Lembaga Pembinaan Khusus Anak Tangerang dengan nilai $p$ value yaitu 0,218 ( $p$ value > $0,05)$.

\section{PEMBAHASAN}

\section{Hubungan Dukungan Sosial dengan Tingkat Depresi}

Hasil analisis data menunjukkan bahwa terdapat hubungan antara dukungan sosial dengan tingkat depresi pada narapidana anak di LPKA Tangerang dengan nilai $p$ value 0,022 .Menurut hasil penelitian ini, responden dengan dukungan sosial rendah paling banyak mengalami tingkat depresi sedang, yaitu 23 responden (46,9\%).Hasil penelitian ini didukung oleh hasil penelitian dari Beyen, Dadi, Dachew, Muluneh \& Bisetegn (2017), yang menyebutkan bahwa adanya hubungan dukungan sosial dengan tingkat depresi dengan nilai $p$ value 0,006 .

Kurangnya dukungan sosial selama dipenjara merupakan salah satu penyebab depresi dan alasan untuk bunuh diri pada narapidana.Hasil penelitian oleh Beyen, Dadi, Dachew, Muluneh \& Bisetegn (2017), tahanan yang mendapatkan dukungan sosial yang baik $62 \%$ lebih rendah kemungkinannya mengalami tanda dan gejala depresi apabila dibandingkan dengan narapidana yang tidak memiliki dukungan sosial. Dukungan sosial pada narapidana rendah karena adanya pembatasan interaksi dan isolasi dari jaringan sosial.Banyak penelitian tentang populasi yang berbeda juga menunjukkan bahwa depresi tinggi terjadi diantara individu dengan dukungan sosial yang rendah. Alasan yang mungkin dijelaskan ialah dengan kurangnya dukungan sosial dapat menyebabkan peningkatan tekanan psikologis (psikologis distres).

Dukungan sosial dari berbagai bentuk dirasakan dapat menjadi pelindung terhadap berbagai kesehatan psikologis, seperti salah satunya ialah depresi (Kao et al, 2014). Dukungan sosial baik dari keluarga dan teman merupakan koping utama. Secara khusus dijelaskan oleh Friedman, Bowden \& Jones (2009), ialah karena dukungan sosial dianggap dapat mengurangi atau menyangga dampak stres serta mengurangi dampak negatifnya, dengan kata lain dukungan sosial dapat menjadi strategi koping penting yang harus ada dalam masa stres.Dukungan sosial juga dipengaruhi oleh pemberi dan penerima dukungan sosial, karena kedua hal tersebut menjadi kunci untuk membentuk dukungan sosial yang efektif (Videbeck, 2011).Individu yang memiliki kebutuhan akan dukungan sosial harus merasakan tindakan yang diberikan oleh pemberi dukungan secara konsisten, dukungan yang diberikan oleh pemberi juga harus sesuai dengan apa yang dibutuhkan oleh penerima dukungan. Calon penerima dukungan juga harus memiliki kemampuan untuk mencari pertolongan bila diperlukan.

Dukungan sosial yang rendah pada narapidana dapat diakibatkan karena beberapa faktor baik dari sistem pemberi dukungan dan penerima dukungan. Adanya pembatasan interaksi antara keluarga dan narapidana serta tidak adanya sumber daya yang dapat memberikan dukungan sosial secara konsisten yang dirasakan oleh narapidana. Menurut hasil analisis data terdapat 7 responden $(7,5 \%)$ yang tidak menerima kunjungan selama di LPKA menyatakan adanya perasaan sedih dan saat menghadapi masalah responden mengharapkan adanya petugas yang mendengarkan keluh kesahnya. Selain itu, faktor dari internal narapidana itu sendiri, dimana menurut hasil wawancara terkadang narapidana anak tidak mau meminta bantuan ketika memiliki masalah dikarenakan adanya perasaan takut ditolak atau adanya perasaan senggan.

\section{Hubungan Appraisal Support dengan Tingkat Depresi}

Analisis data pada penelitian ini menyatakan bahwa terdapat hubungan antara appraisal support dengan tingkat depresi pada narapidana anak di LPKA Tangerang dengan $p$ value 0,024. Hasil menunjukkan, responden dengan appraisal support yang rendah sejumlah 47 responden $(50,5 \%)$, mengalami depresi tingkat sedang paling banyak yaitu sejumlah 23 responden $(48,9 \%)$, sedangkan responden appraisal support tinggi sejumlah 46 (49,5\%), mengalami depresi ringan paling banyak yaitu 17 responden $(37,0 \%)$. Appraisal support ialah komunikasi yang memberikan informasi, dimana informasi tersebut adalah hal yang berguna atau dibutuhkan. Saat menghadapai situasi yang menantang, seringkali dibutuhkan informasi untuk membuat keputusan (Mattson \& Hall, 2011).Appraisal support juga dapat diberikan dalam bentuk saran dan bimbingan mengenai berbagai tindakan untuk memecahkan suatu masalah (Martinez, 2008). Narapidana remaja yang dipenjara sering menghadapi tantangan hidup yang lebih rentan dibandingkan 
dengan populasi remaja pada umumnya, masalah yang berkaitan dengan kesejahteraan hidup dipenjara baik kesejahteraan fisik dan kesehatan mental (Terry, 2012).Masalah yang sering dimiliki oleh narapidana dan dapat menyebabkan depresi ialah seperti tindak kekerasan yang diterima, kurangnya privasi dan aktivitas berarti, masalah kesehatan, dan kekhawatiran mengenai masa depan (Terry, 2012). Sumber daya pemberi dukungan appraisal support selama ditahanan terbatas, hasil penelitian menyatakan bahwa narapidana yang tidak memiliki teman dekat selama di penjara sebanyak 243 narapidana $(37,3 \%)$ dari jumlah total 649 (Beyen, Dadi, Dachew, Muluneh \& Bisetegn, 2017). Menurut Rustam (1994) dalam Sulastri (2013), narapidana selama berada ditahanan tidak menceritakan masalah yang dimiliki kepada keluarga dengan alasan tidak ingin menambah beban keluarga. Menurut tahap perkembangan remaja pada kesehatan psikologis, remaja memiliki perasaan ketidakmampuan atau kesulitan untuk bertanya atau meminta bantuan (Hockenberry \& Wilson, 2015).

Manfaat appraisal support dijelaskan sebagai protection motivation theory antara koping adaptif (coping appraisal) (Fry \& PrenticeDunn, 2005 dalam Ireland, 2011). Appraisal support seperti bentuk motivasi dapat membentuk respon adaptif sebagai proteksi kesehatan psikologis individu (Ireland, 2011). Sebaliknya, apabila appraisal support rendah, dapat membentuk respon maladaptif seperti menyebabkan munculnya perilaku berisiko yang dapat mengancam kesehatan individu.

Appraisal support yang rendah pada narapidana anak di LPKA mungkin disebabkan karena beberapa faktor. Sebelum berada di LPKA peran pemberi dukungan dalam bentuk nasihat dan saran, dapat didapatkan dari orang tua atau teman sekolah. Selama masa penahanan, interaksi anak dan orang tua menjadi terbatas, sehingga menyebabkan berkurangnya peran yang dimiliki orang tua sebagai pemberi nasihat, sehingga menyebabkan rendahnya tingkat dukungan (appraisal support) pada narapidana. Selain itu juga terdapat keterbatasan pemberi dukungan yang dapat mendengarkan cerita narapidana anak. Beban masalah yang dimiliki anak selama di LPKA, keterbatasan sumberdaya, dan adanya ketidakmampuan untuk mengungkapkan dan meminta bantuan seperti saran, dan nasehat menyebabkan anak lebih rentan mengalami depresi.

\section{Hubungan Belonging Support dengan Tingkat Depresi}

Bersarkan hasil analis data menunjukkan bahwa belonging support memiliki hubungan dengan tingkat depresi dengan $p$ value 0,001 . Responden dengan belonging support yang rendah paling banyak mengalami tingkat depresi sedang yaitu sebanyak 20 (47,6\%), dan responden dengan belonging support tinggi paling banyak mengalami depresi minimal sebanyak 21 responden $(41,2 \%)$.

Hasil penelitian secara khusus mencatat bahwa belonging support tampaknya lebih penting dalam mengurangi depresi pada narapidana karena dapat meningkatkan kesejahteraan emosional narapidana (Martinez, 2008). Belonging support, dukungan yang diberikan dengan adanya pembuktian mengenai adanya perasaan cinta, peduli, simpati, dan perasaan positif lainnya (Kaakinen, Coehlo, Steele \& Robinson, 2015). Belonging support dapat dapat datang dari teman, keluarga, bahkan penyedia layanan. Narapidana anak memiliki kebutuhan akan dukungan sosial baik berupa emosional seperti sebuah ekspresi empati dan perhatian yang hanya pada orang tersebut (De Claire \& Dixon, 2016).Pembatasan interaksi antara narapidana anak dengan orang tua dapat menyebabkan anak menunjukkan tanda-tanda depresi, karena keluarga berfungsi sebagai tempat pelabuhan atau istirahat, pemulihan dan membantu penguasaan emosional (Friedman, Bowden \& Jones, 2009; Hockenberry \& Wilson, 2015).

Dampak penahanan pada narapidana anak salah satu nya ialah lose of good and service, dampak ini ditandai dengan hilangnya pelayanan yang mengakibatkan narapidana kehilangan rasa kasih sayang dan rasa afeksi yang biasa didapat dirumah (Badan Penelitian dan Pengembangan HAM, 2014). Pengaruh kunjungan keluarga terhadap kesejahteraan tahanan dan perilaku masa depan merupakan pertimbangan penting dalam pengembangan kebijakan penjara (De Claire \& Dixon, 2016).

Menurut Ron (2004), sense of belonging sebagai konsep kesehatan mental seseorang. Menurut Maslow (1954) dalam Ron (2004), mengidentifikasi bahwa belonging sebagai kebutuhan dasar manusia. Semua anak dan manusia ingin mendapatkan sense of belonging 
baik didalam keluarga, disekolah dengan teman, atau dengan rekan kerja. Kurangnya dukungan sosial dari belonging support pada anak dapat menyebabkan anak memiliki manifestasi dalam gangguan emosional dan psikologis pada perkembangnya, hal tersebut dapat menghambat kemampuan anak untuk menguasai tugas-tugas setiap tahap tumbuh kembangnya (Steinberg, Chung, \& Little,2004 dalam Terry, 2012). Sehingga, kebutuhan akan belonging support selama narapidana anak berada tahanan penting untuk mencegah dampak adanya gangguan kesehatan mental seperti depresi.

Belonging support yang rendah di LPKA dapat terjadi mungkin karena narapidana anak tidak mendapat kunjungan secara konsisten dari keluarga. Menurut hasil wawancara dengan petugas kesehatan, narapidana anak yang mendatangi psikolog di LPKA mengungkapkan kesedihannya karena tidak dikunjungi oleh keluarga dalam waktu lama. Perpisahan dengan orang tua karena penahanan merupakan salah satu stresor bagi narapidana anak, penahanan dapat membuat narapidana kehilangan rasa kasih sayang dan rasa afeksi yang biasa didapat dirumah. Tingginya belonging support pada penelitian ini dikarenakan masih terjalinnya hubungan narapidana anak dengan keluarga melalui kunjungan. Selain itu, adanya beberapa kegiatan yang dilakukan bersama-sama oleh narapidana anak juga dapat meningkatkan belonging support melalui kehadiran temanteman yang dirasakan oleh narapidana. Adanya kunjungan dan kegiatan yang dilakukan bersama teman menumbuhkan sense of belonging yang memungkinkannarapidana anak mengalami depresi lebih rendah.

\section{Hubungan Tangible Support dengan Tingkat Depresi}

Berdasarkan hasil analisis data menyatakan bahwa tidak ada hubungan antara tangible support dengan tingkat depresi dengan nilai $p$ value 0,218 (>0,005). Sejalan dengan penelitian ini, menurut Sulastri (2013), hasil penelitiannya menyatakan bahwa tidak ada hubungan antara dukungan instrumental dengan tingkat stres pada narapidana anak. Berbanding terbalik dengan hasi penelitian yang dilakukan oleh Terry (2012), menyatakan tangible support dari sumber dukungan formal ditahanan memiliki hubungan dengan kesehatan mental narapidana anak selama ditahanan. Menurut Terry (2012), salah satu yang harus diperhatikan ialah dukungan yang diberikan sesuai dengan masalah yang dirasakan oleh narapidana saat itu.

Dukungan instrumental atau tangible support ialah dukungan nyata yang diberikan dalam bentuk wujud barang, seperti bantuan keuangan, barang, atau layanan (Kaakinen, Coehlo, Steele \& Robinson, 2015). Dukungan ini juga disebut dengan dukungan nyata, dimana merupakan bantuan fisik yang diberikan oleh jaringan sosial seseorang (Terry, 2012). Jaringan sosial ini terdiri dari dukungan formal yang diberikan oleh organisasi (seperti sekolah, gereja, program kesejahteraan), dan bantuan tidak resmi yang diberikan oleh orang-orang dalam kehidupan (yaitu keluarga dan teman). Tangible support menjadi salah satu aspek keterampilan dalam mengatasi masalah (Terry, 2012). Menurut Sulastri (2013), 40,8\% narapidana anak mengalami masalah yaitu kekhawatiran memikirkan masa depan setelah keluar dari LPKA. Oleh sebab itu, tangible support dibutuhkan dari sumber formal yaitu lembaga pembinaan khusus anak itu sendiri (Ramchad, Morral, \&Becker, 2009 dalam Sulastri, 2013).

Menurut Visher et al (2004) dalam (Anderson, 2016), narapidana memiliki harapan besar kepada keluarga untuk memberikan tangible support saat narapidana dibebaskan. Alasan tangible support lebih dibutuhkan saat narapidana keluar dari penjara ialah karena tingginya tekanan hidup sehari-hari (seperti kesulitan melanjutkan pendidikan, mencari pekerjaan, dan kekurangan kemampuan finansial) dapat membuat narapidana lebih berisiko kembali melakukan tindakan pidana. Tangible support yang diberikan keluargakepada narapidana yang kembali ke masyarakat termasuk memberikan materi atau sumber daya nyata termasuk tempat tinggal, uang, transportasi, dan pekerjaan (Taylor, 2015 dalam Anderson, 2016). Melalui dukungan tersebut dapat membantu individu bertahan hidup dengan menerima kebutuhan sehari-hari sampai individu mampu menjadi mandiri setelah keluar dari penjara (Breese, et al., 2000 dalam Anderson, 2016).

Analisa peneliti berdasarkan hasil penelitian ini yang menyatakan tidak adanya hubungan antara tangible support dengan tingkst depresi. Seperti dijelaskan bahwa sumber stresor narapidana anak ialah adanya kekhawatiran mengenai masa depan setelah bebas. Seperti yang dijelaskan bahwa stresor narapidana anak ialah adanya 
kekhawatiran mengenai masa depan setelah bebas. Pihak LPKA telah memberikan pelayanan dan fasilitas yang digunakan untuk mengatasi masalah tersebut, yaitu dengan memberikan fasilitas pendidikan (seperti kelas, laboratorium komputer, pelatihan kerja dibidang otomotif) yang dapat mengurangi tingkat depresi karena mengkhawatirkan masa depan setelah bebas. Selain itu, penelitian ini lebih dominan menggali sumber pemberi dukungan dari sumber informal (keluarga dan teman), sedangkan keluarga dan teman di LPKA memiliki berbagai keterbatasan dalam pemenuhan memberikan dukungan tangible support untuk mengatasi masalah yang dirasakan. Oleh sebab itu, seharusnya muncul keseimbangan untuk meneliti dukungan nyata yang diberikan dari sumberi pemberi dukungan baik dari sumber informal (keluarga dan teman) dan formal (program atau barang yang disediakan oleh LPKA) yang sesuai dengan masalah yang dimiliki narapidana anak.

\section{SIMPULAN DAN SARAN}

\section{Simpulan}

Hasil penelitian ini menjelaskan bahwa ada hubungan dukungan sosial (appraisal support dan belonging support) dengan tingkat depresi.

\section{Saran}

Perlu adanya upaya pencegahan dan penanganan untuk depresi pada narapidana seperti skrining awal dan berkala mengenai kesehatan mental, terapi kognitif dan dan psikoedukasi, serta meningkatkan dukungan sosial untuk narapidana.

\section{DAFTAR PUSTAKA}

Anderson, C. R. (2016). The impact of family support on juvenile recidivism (Order No. 10306258). Available from ProQuest Dissertations \& Theses Global. (1861118420). Retrieved from https://search.proquest.com/docview/186 1118420 ?accountid $=17242$

Badan Penelitian dan Pengembangan HAM. (2014). Penerapan hak-hak narapidana di lembaga pemasyarakatan ditinjau dari perspektif hak asasi manusia (HAM). Jakarta : Percetakan Pohon Cahaya

Beyen, T., Dadi, A., Dachew, B., Muluneh, N., \& Bisetegn, T. (2017). More than eight in every nineteen inmates were living with depression at prisons of Northwest Amhara Regional State, Ethiopia, a cross sectional study design. $B M C$ Psychiatry, 17(1).

http://dx.doi.org/10.1186/s12888-016$\underline{1179-9}$

Claire, K., \& Dixon, L. (2016). The effects of prison visits from family members on prisoners' well-being, prison rule breaking, and recidivism. Trauma, Violence, \& Abuse, 18(2), 185-199. http://dx.doi.org/10.1177/152483801560 $\underline{3209}$

Farinde, A., (2013). The beck depression inventory. The Pharma InnovationJournal, 2277-7695. http://www.thepharmajournal.com/archiv es/2013/vol2issue1/PartA/1.pdf

Fazel, S., \& Baillargeon, J. (2011). The health of prisoners. The Lancet, 377(9769), 956965. http://dx.doi.org/10.1016/s0140$\underline{6736(10) 61053-7}$

Friedman, M., Bowden, V., \& Jones, E. (2009). Keperawatan keluarga: Riset, teori, \& praktik (Edisi ke 5) (Prof. Achir Yani, Agus Sutarna, Nike Budhi S, Devi Yulianti, \& Novayanti Herdina, Penerjemah). Jakarta : EGC

Geitona, M., \& Milioni, S. (2016). Health status and access to health services of female prisoners in Greece: a cross-sectional survey. BMC Health Services Research, 16(1).http://dx.doi.org/10.1186 /s12913-016-1506-3

Hockenberry, M.J., \& Wilson, D.(2015). Wong's nursing care of infants and children (10th ed).Canada : Elsevier

Ireland, J. L. (2011). The importance of coping, threat appraisal, and beliefs in understanding and responding to fear of victimization: Applications to a male prisoner sample. Law and Human Behavior, 35(4), 306-315. doi:http://dx.doi.org/10.1007/s10979010-9237-1

Kaakinen, J., Coehlo, D., Steele, R., \& Robinson, M. (2015). Family health care nursing: Theory, practice, and research (5th ed). USA : F.A. Davis Company 
Kao, J., Chuong, A., Reddy, M., Gobin, R., Zlotnick, C., \& Johnson, J. (2014). Associations between past trauma, current social support, and loneliness in incarcerated populations. Health \& Justice, 2(1), 7. http://dx.doi.org/10.1186/2194-7899-2-7

Martinez, D. J. (2008). Homeward bound: Examining social support among former prisoners and their family members (Order No. 3309077). Available from ProQuest Dissertations \& Theses Global. (304415427). Retrieved from

https://search.proquest.com/docview/304 $\underline{415427 \text { ?accountid }=17242}$

Mattson, M., \& Hall, J. G. (2011). Linking health communication with social support. Iowa: Kendall Hunt Publishing Company.

Neufeld, A., \& Harrison, M. (2010). Nursing and family caregiving. New York: Springer.
Sulastri. (2013). Hubungan dukungan sosial dengan tingkat stres anak pidana di lapas anak pria tangerang. Diakses 20 Desembeer 2017, dari http://lib.ui.ac.id/naskahringkas/201509/S46589-sulastri

Terry, D. J. (2012). Social supports and criminal desistance among formerly incarcerated youth in the transition to adulthood (Order No. 3527490). Available from ProQuest Dissertations \& Theses Global. (1095380368). Retrieved from

https://search.proquest.com/docview/109 5380368? accountid $=17242$

Videbeck, S.L. (2011). Psychiatric-mental health nursing (5th ed). Philadelphia, PA: Wolters Kluwer/Lippincott Williams \& Wilkins. 